
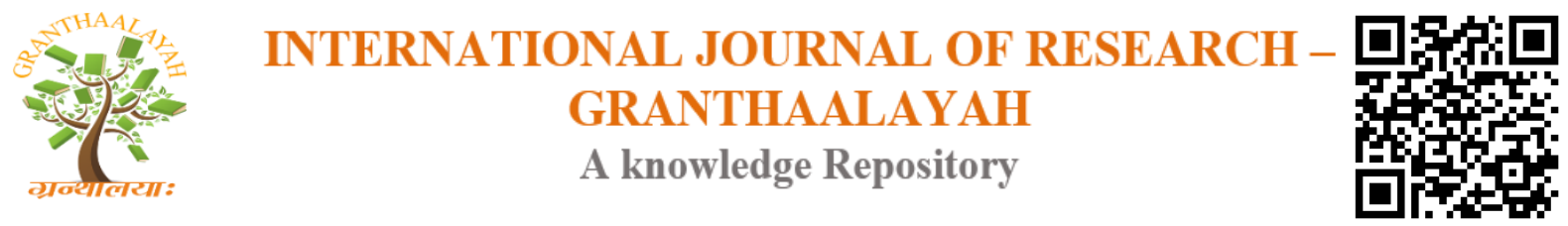

Science

\title{
DESIGN AND IMPLEMENTATION OF VIRTUAL UNIVERSITY BASED ON ICT
}

\author{
Chris Batara ${ }^{1}$, Charnia Iradat Rapat ${ }^{2}$ \\ ${ }^{1,2}$ Electrical Engineering, UKI Paulus, Indonesia
}

\begin{abstract}
Virtual University is a learning system by providing an online environment based on information and communication technology. This system can overcome the problems that arise due to covid19 not to gather together to do the learning process, but must learn from their respective places. This Virtual University system uses Moodle version 3.7 with PHP and MySql programming language platforms as a database server and Apache as a web server can be an innovative learning method that is an ideal solution and in accordance with existing conditions with the hope that it can improve the quality of education if used optimally and comprehensive. This system can perform the basic functions of an e-learning system in which the lecturer can upload lecture material and students can download the material online and can conduct online meetings that can replace face to face in the room.

The general objective of this research is to apply a web-based online learning system. The system applied is software that supports the ongoing teaching and learning process for online learning through the internet. The software is installed on the server and can be accessed by participants of online learning programs from browser applications on their PC / cell, and the formation of a university that is not limited by time and space.

The stages of this research are: determining user needs, creating a system model, design, system implementation, and testing.
\end{abstract}

Keywords: Virtual University; Online; Interaction; Moodle; Covid-19.

Cite This Article: Chris Batara, and Charnia Iradat Rapat. (2020). "DESIGN AND IMPLEMENTATION OF VIRTUAL UNIVERSITY BASED ON ICT." International Journal of Research - Granthaalayah, 8(4), 144-152. https://doi.org/10.29121/granthaalayah.v8.i4.2020.19.

\section{Introduction}

\section{Background}

In general, traditional education programs are carried out at a certain time and location, where the instructor / lecturer or student gather to hold interactions in the teaching and learning process, education or training. However, sometimes obstacles arise that do not allow the traditional education program to be implemented properly. One of the main obstacles in carrying out traditional education is the geographical location of the scattered community. Not in the same 
location and time as the resource person. These location constraints cause inefficiency if someone may attend an education or training in a particular location that is separate from the location where the person is located. Inefficiencies that arise include in terms of time, cost, and energy that must be provided to reach the location of education / training.

Limited space and time are the main obstacles for improving the quality of teaching. Increasing the number of students in an institution has the potential to reduce interactions between teachers and students so that the desired results are less than optimal, in terms of quality education getting further from expectations.

\section{Formulation of The Problem}

Realizing the importance of education and knowledge which is the capital to bring people to a more advanced direction with a very strong positive influence in creating a change, then a university must always improve the quality and education system in its scope of work. One aspect that requires development by taking into account the use of information technology and internet technology is a learning method that only relies on conventional media in the classroom.

With a learning model that utilizes information technology and internet technology, it is possible for teaching activities to continue effectively and efficiently even though it is limited by space and time so that it benefits both students and universities.

Appropriate technology is technology that can be used maximally for public use.

\section{Research Purposes}

The general objective of this research is to design a learning system that provides an ict-based online learning environment that can be used anytime and anywhere as long as an internet connection is available.

Special Purpose: the formation of a virtual university that is not limited by space and time.

\section{Expected Output}

Moodle-based virtual university

\section{Usability of The Program}

The benefits obtained with this learning model are:

- Virtual universities can deal with two problems in conventional learning (face to face), namely the problem of time and cost. With the availability of a virtual university, the online teaching and learning process can be held which is not bound by time and space in its implementation.

- distance learning can be implemented interactively, so it is very interesting for learners.

- increase awareness and skills in working with icts

- provide new learning modes that can enrich the learning process undertaken by students. 


\section{Materials and Methods}

\subsection{E - Learning (Electronic - Learning)}

The term e-Learning contains a very broad understanding, so that many experts describe the definition of e-Learning from various points of view. One definition that can be accepted by many parties, for example from Darin E. Hartley [Hartley, 2001] states:

"E-Learning is a type of teaching and learning that enables the delivery of teaching materials to students using the Internet, Intranet or other computer network media."

LearnFrame.Com in the Glossary of e-Learning Terms [Glossary, 2001] states a broader definition that:

"E-Learning is an education system that uses electronic applications to support teaching and learning with Internet media, computer networks, and standalone computers."

One example of an e-Learning system is that which is implemented by the Cisco Systems company for the Cisco Networking Academy Program (CNAP). This is an example of a successful eLearning system, which has been used by all CNAP academy levels, both CATC (Cisco Academy Training Center), Regional Academy and Local Academy.

\section{E-Learning Applications from Time to Time}

A brief description of the development of e-Learning from time to time is as under [Cross, 2002]: 1990: CBT (Computer Based Training)

An era in which e-Learning applications began to emerge that were running on standalone PCs or in the form of CD-ROM packaging. Content in the form of material in the form of text or multimedia (video and audio) in MOV, MPEG-1 or AVI format. Macromedia software company released a development tool called Authorware, while Asymetrix (now Click2learn) also developed software called Toolbook.

\section{4: CBT Packages}

Along with the acceptance of CBT by the community, since 1994 CBT has emerged in the form of more attractive and mass-produced packages.

\section{7: LMS (Learning Management System)}

Along with the development of internet technology in the world, the world community is connected to the Internet. The need for fast information is absolute, and distance and location are no longer obstacles. This is where the term Management Learning System appears or commonly abbreviated as LMS. The rapid development of LMS makes new thinking to overcome the problem of interoperability between existing LMS with a standard. Emerging standards such as AICC (Airline Industry CBT Committee) standards, IMS, ARIADNE, etc. 


\section{9: Web Based e-Learning Applications}

The development of LMS leads to a total Web-based e-Learning application, both for learners and teaching and learning administration. LMS began to be combined with portal sites which at this time could be said to be a barometer of information sites, magazines, and world newspapers. With a mix of multimedia, video streaming, interactive appearance, a choice of more data formats, as well as smaller and stable sizes.

\subsection{Approach Method}

An outline of the research approach can be seen as follows:

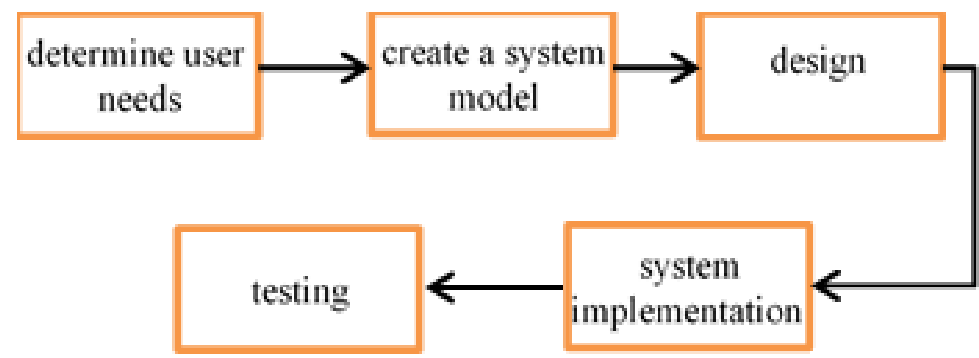

Figure 1: Outline of the research approach

The first phase of this study began with the determination of user needs, including those obtained from observations of the educational process contained in Paul's UKI. From the observations known functions or activities that will be applied in the system. The second stage is to analyze and model the functions that will be applied. Then the third stage is to complete the process of designing the system software (selecting program packages which are appropriately suitable for building systems). The fourth stage with the results of the design is implemented and the fifth stage is the final stage of testing.

\section{Results and Discussions}

\subsection{Determine User Needs}

Before designing a system, the user needs are determined first which includes capabilities and technical specifications that must be owned by the system. From this first stage will be obtained a need and specifications for the system that will be a reference in the implementation of subsequent stages.

From observations made on UKI Paulus the user needs are as follows:

- Provide subject matter

- Provides a means for discussion

- Provides face to face facilities

- Provides a means for testing

- Has student and teacher data storage facilities

- Enables students to do the learning process independently.

- The system is "user friendly"

- Walk on a standard multimedia PC. 


\section{Business Process}

From the business process, it can be seen the functions that must be performed by the system. The business processes that will be applied in the system are shown in the following figure:

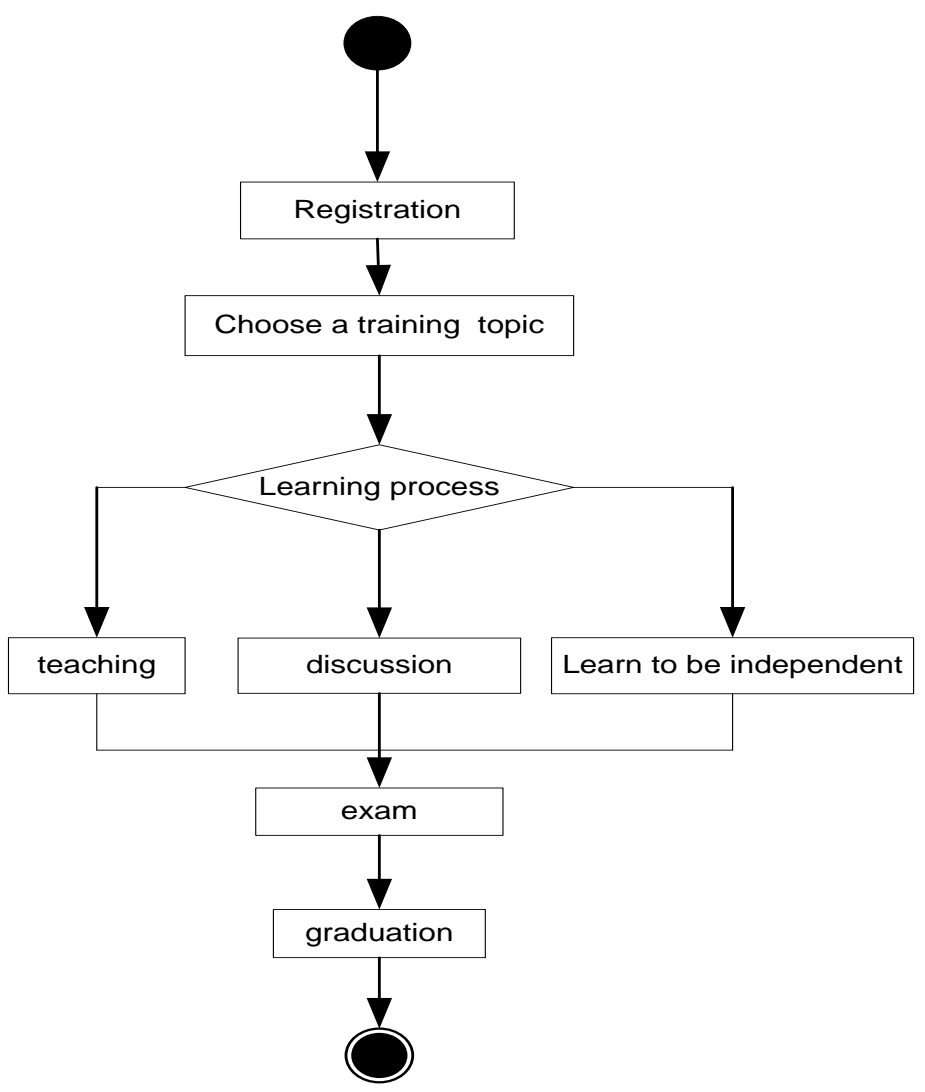

Figure 2: Business Process Systems

Based on the business processes above, functions in the system are designed to cover registration, selection of training topics, teaching, discussion, examinations, and graduation determination.

\subsection{Make Model}

Based on user needs, an analysis is performed to explain all user needs so that a model that describes the needs of users is obtained.

The first step in the analysis is to define the use case, which describes the functions provided by the system. In defining the use case is also determined by the actor, namely someone or something that interacts with the system or in other words the actor is running the use case. Actors in this elearning system are defined as three: students or participants, instructors or facilitators, and administrators. The student is the person who follows the training provided by the system, the instructor is the person responsible for the ongoing curriculum of a training, and the administrator is the person responsible for administration. The three actors can interact directly with the system, namely the system use cases. A list of related actors and use cases can be seen in the following table: 
Table 1: Actors and Use case

\begin{tabular}{|c|c|}
\hline Actors & Use Case \\
\hline Student & $\begin{array}{l}\text { Registration } \\
\text { Selection of Training Topics } \\
\text { Teaching } \\
\text { Discussion } \\
\text { On line Test } \\
\text { Take a Home Test } \\
\text { practice } \\
\text { Student Data Correction }\end{array}$ \\
\hline Teacher & $\begin{array}{l}\text { Teaching } \\
\text { Discussion } \\
\text { Correction of exam results } \\
\text { Graduation Determination } \\
\text { Teaching Data Correction }\end{array}$ \\
\hline Administrator & Can do anything to this system \\
\hline
\end{tabular}

Analysis of user needs are documented in use case diagrams that illustrate the relationship between actors and related use cases.

Use case diagrams include all system functionalities that reflect both synchronous and asynchronous systems. Functions related to synchronous systems are real time teaching and discussion. While other functions are related to asynchronous systems.

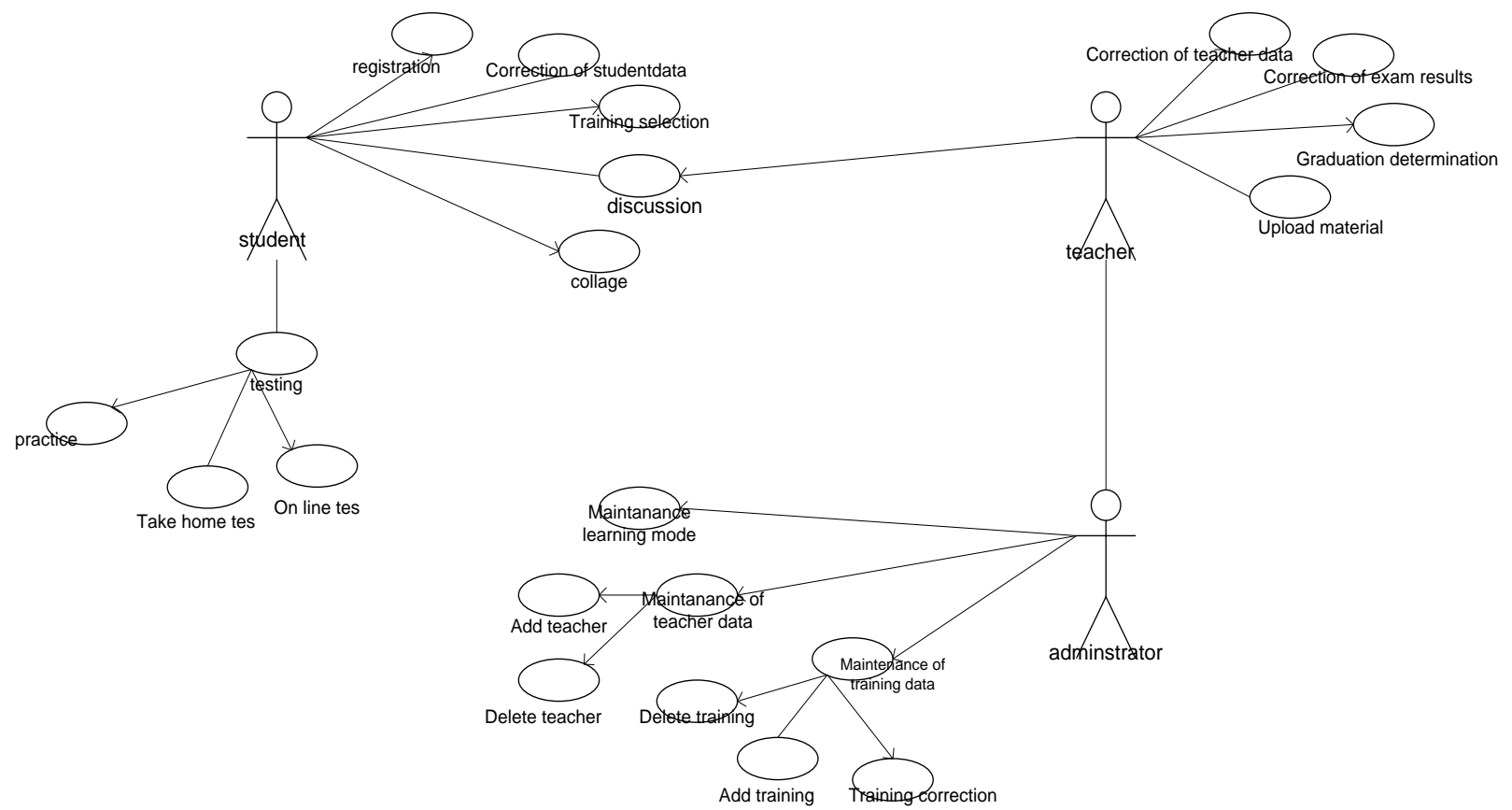

\subsection{Design}

Figure 3: Use Case

In this research we use "open source Moodle" software, a web-based learning system that can be configured according to the needs of the user. 
In this stage we do Moodle configuration that is tailored to the needs of users obtained at the stage of determining user needs, namely based on the business processes stated above.

\section{Provides Subject Matter}

The system provides subject matter where information is stored in class material. A training can consist of one or many materials. If needed material can be downloaded from a certain directory.

\section{Provides A Means for Discussion}

As a means of discussion, the system has two types of discussion, which are reflected in open discussion use cases, and closed discussion use cases. Open discussion can be carried out using forums. Closed discussion using chat.

Open discussion where the content of the discussion is displayed through a bulletinboard that can be read by many people. Means for discussion through the bulletinboard are provided because there are things that need to be discussed by many parties. Through the bulletinboard media, it is expected that for the problems that arise the best possible solution is obtained.

If the final discussion is a closed discussion, where students can send letters through the e-mail system to the teacher without anyone knowing or chatting. Closed discussion facilities are provided because there are certain times when a student needs to discuss or get information directly from the teacher without wanting to be known by others.

\section{Provides a Means for Testing}

There are three types of exams provided by the system namely on line test, take hame test, and practice. While the supporters of the class use case exams are the class of Test Questions, Exam Schedules, Exam Answers, and Test Values.

\section{Has student and teacher data storage facilities.}

Student and teacher data is stored in a database.

Allows students to do the learning process independently.

The subject matter is provided by the system, therefore students can easily browse the required subject matter themselves. With the availability of subject matter that can easily be traced and lowered, the availability of facilities for discussion, and facilities for participating in teaching for those who need it, as well as the testing function, it is hoped that students can carry out the learning process independently.

The system is "user friendly"

The displays in the system use a GUI, simple but complete containing the required information. To move from one screen to the next the student just presses the button or hyprlink provided. Walk on a standard multimedia PC.

A standard multimedia PC can be defined as a PC or personal computer that can be used to run multimedia applications. 
Table 2: User needs, solutions and reasons for solutions

\begin{tabular}{|c|c|c|}
\hline User Needs & Solution (Design Results) & Reasons for Choosing a Solution \\
\hline $\begin{array}{l}\text { A combination of } \\
\text { synchronous and } \\
\text { asynchronous } \\
\text { systems }\end{array}$ & $\begin{array}{l}\text { Sync: } \\
\text { Teaching process } \\
\text { Real time discussion } \\
\text { Asynchronous: } \\
\text { open discussion } \\
\text { Closed discussion } \\
\text { Provision of material on the web }\end{array}$ & $\begin{array}{l}\text { Real time teaching and discussion } \\
\text { is a reflection of the traditional } \\
\text { educational process that is } \\
\text { sometimes still needed }\end{array}$ \\
\hline $\begin{array}{l}\text { Use the tools } \\
\text { available in the } \\
\text { market }\end{array}$ & $\begin{array}{l}\text { The system provides conference } \\
\text { facilities for teaching and uses e- } \\
\text { mail systems and buliten boards } \\
\text { for discussion. File transfer is } \\
\text { used for sending exam results }\end{array}$ & $\begin{array}{l}\text { Telecollaboration tools for } \\
\text { conducting conferences on the } \\
\text { internet as well as e-mail systems, } \\
\text { bulletin boards, and transfer files } \\
\text { with good quality are already } \\
\text { widely available in the market. }\end{array}$ \\
\hline $\begin{array}{l}\text { Provide a means of } \\
\text { discussion }\end{array}$ & $\begin{array}{l}\text { Three types of discussion } \\
\text { facilities are provided, namely } \\
\text { real time discussion, open } \\
\text { discussion, and closed } \\
\text { discussion. }\end{array}$ & $\begin{array}{l}\text { Not all problems can be solved } \\
\text { through one form of discussion. } \\
\text { There are issues that need to be } \\
\text { discussed with many parties or } \\
\text { simply resolved only by the } \\
\text { instructor. }\end{array}$ \\
\hline $\begin{array}{l}\text { Providing testing } \\
\text { facilities }\end{array}$ & $\begin{array}{l}\text { Three types of testing facilities } \\
\text { are provided, namely online } \\
\text { tests, take home tests, and } \\
\text { exercises. }\end{array}$ & $\begin{array}{l}\text { Each material has its own type of } \\
\text { test, so some testing facilities need } \\
\text { to be provided. }\end{array}$ \\
\hline $\begin{array}{l}\text { Has student and } \\
\text { teacher data storage } \\
\text { facilities }\end{array}$ & $\begin{array}{l}\text { Teacher data is stored in the } \\
\text { domain class of people, teacher } \\
\text { information, and student } \\
\text { information }\end{array}$ & $\begin{array}{l}\text { Superclass and subclass structures } \\
\text { are created because the two } \\
\text { subclasses have many of the same } \\
\text { attributes and only a few attributes } \\
\text { that distinguish the two subclasses }\end{array}$ \\
\hline $\begin{array}{l}\text { Provide subject } \\
\text { matter }\end{array}$ & $\begin{array}{l}\text { Each training consists of one or } \\
\text { more materials stored in class } \\
\text { material }\end{array}$ & $\begin{array}{l}\text { A training has the scope and level } \\
\text { of complexity of each. For this } \\
\text { reason the system must } \\
\text { accommodate the possibility that a } \\
\text { training may consist of one or more } \\
\text { materials }\end{array}$ \\
\hline $\begin{array}{l}\text { Enable students to } \\
\text { do the teaching and } \\
\text { learning process } \\
\text { independently }\end{array}$ & $\begin{array}{l}\text { Material is provided on the web } \\
\text { and can be taken down. } \\
\text { Synchronous systems are only } \\
\text { supportive }\end{array}$ & $\begin{array}{l}\text { The web is widely known and easy } \\
\text { to operate }\end{array}$ \\
\hline $\begin{array}{l}\text { Have administrative } \\
\text { aids }\end{array}$ & $\begin{array}{l}\text { Functions are added, corrected, } \\
\text { and deleted data. }\end{array}$ & $\begin{array}{l}\text { These functions are provided to } \\
\text { maintain data accuracy and system } \\
\text { performance. }\end{array}$ \\
\hline Are user friendly & $\begin{array}{l}\text { Three menus on the web: } \\
\text { Student Menu } \\
\text { Teacher's Menu }\end{array}$ & $\begin{array}{l}\text { Each menu has different functions } \\
\text { and related actors. The menu is }\end{array}$ \\
\hline
\end{tabular}




\begin{tabular}{|l|l|l|}
\hline & Administrator Menu & $\begin{array}{l}\text { made simple and web-based. Easy } \\
\text { to operate and uncomplicated }\end{array}$ \\
\hline $\begin{array}{l}\text { The system is easy } \\
\text { to develop for new } \\
\text { functions }\end{array}$ & $\begin{array}{l}\text { The system consists of } \\
\text { subsystems that are grouped } \\
\text { according to functional and } \\
\text { technical } \\
\text { User interface subsystem } \\
\text { Business object subsystem } \\
\text { Object component subsystem } \\
\text { Database subsystem } \\
\text { Utility subsystem }\end{array}$ & $\begin{array}{l}\text { Grouping into several subsystems is } \\
\text { done so that if there is a change in } \\
\text { one subsystem does not much } \\
\text { affect the other subsystems. }\end{array}$ \\
\hline
\end{tabular}

\section{Conclusions and Recommendations}

\subsection{Conclusion}

1) Information Technology can help learning by providing an on-line environment that allows users to go through the learning process in various modes.

2) Information technology is able to overcome physical obstacles in learning, such as class limitations, geographical locations, etc.

3) Allows students to repeat material that is not yet understood.

4) Interaction / discussion between lecturers and students or between students not only in class (physically) but also anytime and anywhere (online).

5) Access to learning material resources through unlimited channels and networks.

\subsection{Recommendations}

this research was developed with a more detailed design for wider implementation:

1) Online library.

2) Providing administrative aids (Academic Information System)

3) Developed for new functions or to meet system requirements.

\section{References}

[1] Suban Mohammed Gouse Saleem, Helen Suban Mohammed Gouse (March, 2018) Influence of Online Learning in Medical Education is Neither Disruptive Nor Supplementary: It's Time to Walk Parallel!

[2] Jaka Fahrial, 2003 "LAN configuration technique", General Lecture of Computer Science.Com, http://www.ilmukomputer.com.

[3] Kukuh Setyo Prakoso, 2005, "Building E-Learning with Moodle", Andi Yogyakarta.

[4] Ir. Resmana, M.Eng and Team, 2005, "Training of Innovative Learning Methods for the Department of Electrical Engineering", Petra Christian University.

[5] http://www.efrontlearning.net.

*Corresponding author.

E-mail address: chrisbatara@ukipaulus.ac.id/ charnia@ukipaulus.ac.id 